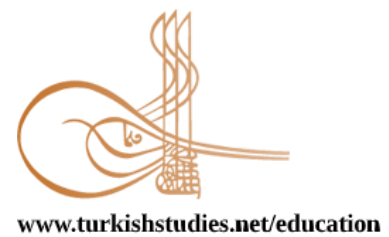

Turkish Studies - Educational Sciences

eISSN: 2667-5609

Research Article / Araștırma Makalesi

\title{
Lise Öğrencilerinin Akademik Öz-yeterlik İnançlarının İncelenmesi
}

\author{
Investigation of High School Students' Academic Self-Efficacy Beliefs
}

\author{
Tuncay Yavuz Özdemir ${ }^{*}$ - Mustafa Orhan ${ }^{* *}-$ Yasin Demir $^{* * *}$
}

\begin{abstract}
In this study, it is aimed to determine the academic self-efficacy levels of students studying in high school education institutions and to examine them in terms of various variables. This research which survey model was used model was carried out with the adolescents studying in the 2018-2019 academic year in the central district of Yakutiye, Erzurum. In the research, 624 high school students were reached with convenience sampling method. The academic self-efficacy scale consists of 7 items and each item is 4-point Likert type. The adaptation to Turkish version of the scale was made in 2007. In the adaptation to Turkish study, it was determined that the items in the scale were collected in one factor and the factor loads of the items were between .50 and .83, and the Cronbach Alpha coefficient, which is the internal consistency coefficient, was .79. In this study, Cronbach Alpha coefficient was calculated as .72. "Academic SelfEfficacy Scale" was used to collect research data. SPSS 22.0 package program was used in the analysis of the data. According to the results of the research, it was determined that high school students' academic selfefficacy beliefs are at the level of "suits me". It was found that there was no significant difference between high school students' opinions about their academic self-efficacy beliefs and their gender and student types. According to the variable of the type of school in which high school students study, it was determined that Science High School students had more positive academic self-efficacy beliefs than Anatolian High School and Vocational High School students. Anatolian High School students were also found to have more positive academic self-efficacy beliefs than Vocational High School students. According to the class variable where high school students study, 9th grade students were found to have more positive academic self-efficacy beliefs than 10th grade students.
\end{abstract}

Structured Abstract: The knowledge and skills that people possess influence their feelings of trust in their own equipment and guide their future actions. Self-efficacy, which is the perception of people about their potential, is the idea that one has the capacity to do something (Akınc1, 2014). Perceived self-efficacy is the

\footnotetext{
${ }^{*}$ Doç. Dr., Frrat Üniversitesi, Eğitim Fakültesi, Eğitim Bilimleri Bölümü

Assoc. Prof. Dr., Firat University, Faculty of Education, Department of Educational Sciences

ORCID 0000-0002-5361-7261

tyozdemir@gmail.com.

** Doktora öğrencisi, Erzurum İl Milli Eğitim Müdürlüğü

Phd Student, Erzurum Provincial Directorate of National Education

ORCID 0000-0002-6254-6733

mustafaorhan2525@hotmail.com.

**** Dr. Öğr. Üyesi, Fırat Üniversitesi, Eğitim Fakültesi, Rehberlik ve Psikolojik Danışmanlık Bölümü

Asst. Prof. Dr., Firat University, Faculty of Education, Department of Guidance and Counseling

ORCID 0000-0002-2456-1449

yasindemir@firat.edu.tr

Cite as/ Atıf: Özdemir, T. Y., Orhan, M. \&, Demir, Y. (2020). Lise öğrencilerinin akademik öz-yeterlik inançlarının incelenmesi. Turkish Studies - Education, 15(3), 1979-1989. https://dx.doi.org/10.29228/TurkishStudies.41965

Received/Geliş: 29 February/Şubat 2020

Checked by plagiarism software

Accepted/Kabul: 05 June/Haziran 2020

Published/Yayın: 25 June/Haziran 2020

Copyright (C INTAC LTD, Turkey

CC BY-NC 4.0
} 
judgment of individuals about their ability to regulate and organize the course of action needed to achieve the specified performance (Bandura, 1986). Expectations of the person towards the outcome of that behavior are effective in exhibiting any behavior (Ağır, 2005). Competence beliefs affect people's thoughts, feelings, motivation and actions (Bandura, 1995). People with a strong sense of competence approach difficult tasks as challenges to overcome rather than threats to avoid (Pajares, 2008).

Academic self-efficacy is the belief of individuals that they can successfully fulfill certain levels of academic tasks (Schunk, 1991). Many factors such as modeling peers' cognitive skills with formal education, comparing with other students' performances, increasing motivation, interpretation of student success and failures by the teacher affect children judgments about their cognitive competencies (Kalkan, 2008). Students' academic success is related to their academic self-efficacy. In the study carried out by Ekinci (2011), there was a positive relationship between students' academic achievement and academic self-efficacy levels. The idea that determining the perceptions of high school students towards their academic potential may contribute to the steps to be taken towards organizing their academic life has been an important issue for the researchers. This research aims to determine the academic self-efficacy levels of students studying in Anatolian, Science and Vocational High Schools and to examine their academic self-efficacy levels according to some variables.

In this research, it is a study carried out in the descriptive survey model that aims to examine students' academic self-efficacy beliefs. It is also a correlational study that examines the relationships between variables. Descriptive research aims to describe an existing situation as close to reality as possible, while correlational studies examine the relationships between variables (Büyüköztürk, Çakmak, Akgün, Karadeniz, \& Demirel, 2016). The universe of the research consists of Anatolian, Science and Vocational High School students studying in the district of Yakutiye, Erzurum, in the 2018-2019 academic year. In the research, a total of 624 Anatolian, Science and Vocational High School students were reached, which were determined by convenience sampling method. The Academic Self-Efficacy Scale (ASE), which was developed by Jerusalem and Schwarzer (1981), and adapted to Turkish by Y1lmaz, Gürçay and Ekici (2007), was used as the data collection tool. The scale consists of 7 items and a single factor. It is a measuring tool with 4 ratings. The scores that can be obtained from the scale vary between 7-28. High scores show a high level of academic-self-efficacy. For statistical solutions of research data, t-test and one-way analysis of variance were applied; frequency, percentage and averages are calculated. In statistical analysis, the significance level was accepted as $\mathrm{p}<0.05$.

It was determined that high school students generally have academic self-efficacy beliefs at the level of "suits me" with an average of 2.63. When the students' academic self-efficacy beliefs are analyzed according to the gender variable; female students average 2.58; On the other hand, it was determined that male students expressed their opinions as "good" with an average of 2.68. It was determined that the academic self-efficacy scores of the female and male students did not differ significantly according to their gender.

When the students' views on academic self-efficacy beliefs were examined, it was found that there was a statistically significant difference according to the school type variable. According to the results of the Scheffe test conducted to determine which groups the differences were, it was observed that the Science High School students $(\bar{x}=2.78)$ had higher academic self-efficacy scores than the Anatolian High School students $(\overline{\mathrm{x}}=2.63)$ and Vocational High School students $(\overline{\mathrm{x}}=2.48)$. Similarly, Anatolian High School students $(\overline{\mathrm{x}}=2.63)$ have significantly higher views on academic self-efficacy beliefs than Vocational High School students $(\overline{\mathrm{x}}=$ 2.48). The reason for this difference may be that the school types that students enter according to the exam results based on their success rankings have shaped their academic self-efficacy perceptions.

When examined according to the level of class they are studying; The opinions of 9th grade students $(\overline{\mathrm{x}}=2.73)$ about academic self-efficacy beliefs are more positive than 10th grade students $(\overline{\mathrm{x}}=2.53)$. Based on the results of this research, some suggestions can be presented. As with any research, there are some limitations in this research. Collecting the study data from a single district and collecting data only with quantitative tools are among the important limitations of this research. In this context, supporting the quantitative data with qualitative data and conducting applications in different regions may lead to healthier evaluations and generalizations. In subsequent research, factors affecting students' academic self-efficacy beliefs can be investigated. This research was carried out to determine the academic self-efficacy belief levels 
of students studying in public high school education institutions. Academic self-efficacy belief levels of students studying in private secondary education institutions can also be investigated.

Keywords: Educational Sciences, self-efficacy, academic self-efficacy belief, high school students, adolescents.

Öz: Bu araştırmada, ortaöğretim kurumlarında öğrenim gören öğrencilerin akademik öz-yeterlik düzeylerinin tespit edilmesi ve çeşitli değişkenler açısından incelenmesi amaçlanmıştır. Tarama modelinin kullanıldığı bu araştırma Erzurum ili merkez Yakutiye ilçesinde 2018-2019 eğitim öğretim yılında öğrenim gören ergenler ile gerçekleştirilmiştir. Araştırmada kolayda örnekleme yöntemi ile 624 lise öğrencisine ulaşılmıştır. Araştırma verilerini toplamak için "Akademik Öz-yeterlik Ölçeği” kullanılmıştır. Akademik öz yeterlik ölçeği toplam 7 maddeden oluşmakta ve her ir madde 4'lü Likert tipindedir. Ölçeğin Türkçe uyarlaması 2007 yılında yapılmıştır. Türkçe uyarlama çalışmasında ölçekte yer alan maddelerin tek faktörde toplandığı ve maddelerin faktör yüklerinin .50 ile .83 arasında olduğu, iç tutarlık katsayısı olan Cronbach Alfa katsayısı .79 olduğu belirlenmiştir. Bu araştırmada Cronbach Alfa katsayısı .72 olarak hesaplanmıştır. Verilerin analizinde SPSS 22.0 paket programı kullanılmıştır. Araştırma sonuçlarına göre lise öğrencilerinin genel olarak akademik öz-yeterlik inançlarının "bana uyuyor" düzeyinde olduğu saptanmıştır. Lise öğrencilerinin akademik öz-yeterlik inançlarına sahip olma düzeylerine ilişkin görüşleri ile cinsiyetleri ve öğrenci tipleri arasında anlamlı bir fark olmadığı saptanmıştır. Lise öğrencilerinin öğrenim gördükleri okul türü değişkenine göre, Fen Lisesi öğrencilerinin Anadolu Lisesi ve Meslek Lisesi öğrencilerinden; Anadolu Lisesi öğrencilerinin ise, Meslek Lisesi öğrencilerinden daha olumlu akademik öz-yeterlik inanç düzeylerine sahip oldukları saptanmıştır. Lise öğrencilerinin öğrenim gördükleri sınıf değişkenine göre, 9. sınıf öğrencilerinin, 10. sınıf öğrencilerine göre daha olumlu akademik öz-yeterlik inanç düzeylerine sahip oldukları saptanmıştır.

Anahtar Kelimeler: Eğitim Bilimleri, öz-yeterlik, akademik öz-yeterlik inancı, lise öğrencileri, ergen.

\section{Giriş}

İnsanların sahip olduğu bilgi ve beceriler, kendi donanımlarına yönelik güven hislerine etki ederek gelecekte gerçekleştirecekleri eylemlerine yön vermektedir. İnsanların kendi potansiyellerine yönelik algıları olan öz yeterlik, kişinin bir şeyi yapmaya kapasitesi olduğuna yönelik düşüncesidir (Akınc1, 2014). Bununla birlikte öz-yeterliğin, kişinin kendisinin farklı durumların üstesinden gelme, belli bir işi gerçekleştirme yetenek ve kapasitesine yönelik algısı (Çakır, 2007), sergilenmesi gereken performans ile kendi yeteneğinin mukayese edilerek duruma göre eylemde bulunulması (Korkmaz, 2011), belirsiz, öngörülemeyen ve stresli özellikler içerebilecek özel durumlarda eylemlerin ne kadar iyi yapılabileceğine dair kişisel yargılar (Schunk, 1984) şeklinde tanımları da bulunmaktadır.

Algılanan öz yeterlik, kişilerin belirlenen performansa ulaşmak için gereken eylemin gidişatını düzenleme ve organize etme kabiliyetlerine dair yargılarıdır (Bandura, 1986). Kişinin herhangi bir davranışı sergilemesinde o davranışın sonucuna yönelik beklentileri etkili olmaktadır (Ağır, 2005). Yeterlik inançları, insanların düşüncelerini, hislerini, kendilerini motive etmelerini ve eylemlerini etkiler (Bandura, 1995). Yeterlik duygusu güçlü olan kişiler, zor görevlere, kaçınılması gereken tehditler yerine üstesinden gelinecek zorluklar olarak yaklaşmaktadır (Pajares, 2008). Kişinin kendisinin yeterli olduğuna inanmaya devam etmesi, başarısızlık deneyiminden sonra dahi, gelecekte karşılaşacağ görevlerin üstesinden gelmeye yönelik çaba/davranış içerisine girmesini sağlamaktadır (Aydın, 2006). Buna karşılık öz yeterliliği düşük olan insanlar, işlerin gerçekteki durumundan daha güç olduğuna inanabilirler. $\mathrm{Bu}$ inanç stresi, depresyonu besler ve problemin çözümünde dar bir vizyon geliştirilmesine yol açar (Pajares, 1996). Bununla birlikte kişiler, belli bir görevi gerçekleştirmek için kendilerini yetkin olarak görebilir, ancak bu görevi yerine getirecek gerekli becerilerden yoksun olabilirler. Bu durumda onların eylemleri iyi olmayacaktır (ÜnAçıkgöz, 2005). 
Yeterlik inançları, onları şekillendiren bilgi ve deneyimlerin nasıl yorumlandığına bağlıdır (Kandemir, 2015). Bandura (1977) da, öz-yeterlik inancının şekillenmesinde bireyin deneyimleri, dolaylı öğrenmeni, ikna yeteneği ile kişinin fizyolojik ve duygusal durumları olmak üzere dört kaynağın etkili olduğunu vurgulamaktadır. Ekinci'ye (2011) göre ise kişinin işe başlama ve devam ettirme sürecinde fizyolojik ve duygusal durumunu değerlendirme şekli, işi bitirebileceğine dair iyimser veya kötümser düşünceleri, öz-yeterliğini etkilemektedir. Öz-yeterlik kavramının akademik alandaki yansıması akademik öz-yeterlik olarak karşımıza çıkmaktadır.

Akademik öz-yeterlik, kişilerin belirli seviyelerdeki akademik görevleri başarıyla yerine getirebileceklerine yönelik inançlarıdır (Schunk, 1991). Formal eğitimle birlikte akranların bilişsel becerilerinin model alınması, diğer öğrencilerin performanslanı ile karşılaştırma yapma, motivasyonu artırma, öğrenci başarı ve başarısızlıklarının öğretmen tarafından yorumlanması gibi birçok faktör çocukların kendi bilişsel yeterlikleri hakkındaki yargılamalarına etki etmektedir (Kalkan, 2008). Algılanan öz yeterlik, eğitimsel yeterliklerin gelişimini destekleyen öğrenme faaliyetlerine katılımı teşvik ettiğinden, motivasyonun yanı sıra başarı seviyesini de etkiler (Zimmerman, 1995). Akademik öz yeterliliği yüksek öğrenciler, öğrenmede etkin bilişsel stratejilerden daha fazla yararlanmakta, zamanlarını ve öğrenme ortamlarını daha etkili bir şekilde yönetmekte ve kendi çabalarını izleme ve düzenleme konusunda daha iyi olmaktadırlar (Chemers, $\mathrm{Hu}$ ve Garcia, 2001). Öz-yeterlik inanc1 yüksek olan öğrenciler "bu sınıfta öğretilenleri öğrenebileceğimi biliyorum" ve "bu etkinlikte iyi bir iş yapabileceğime inanıorum" tarzında ifadelere de sahip olmaktadırlar (Santrock, 2018). Buna karşı1lık kendi yapabilirliklerine yeteri kadar inanc1 olmayan öğrenciler, yeni şeyler öğrenmede yeterli gayreti ortaya koymamakta ve engellere kolaylıkla teslim olmaktadırlar (Kotaman, 2008). Öğretmenlerin öğrencilerinin özyeterlik inançlarını artırabilmeleri için öğretim sürecini öğrencilerin gereksinimlerine göre düzenlemeleri, her bir öğrencinin sahip olduğu özelliklere uygun farklı etkinlikler gerçekleştirmeleri, işbirliğine dayalı öğretim yaklaşımlarını kullanmaları ve öğrencileri değerlendirirken onları birbirleriyle mukayese etmekten uzak durmaları gerekmektedir (Senemoğlu, 2015).

Öğrencilerin akademik başarıları onların akademik öz-yeterlikleri ile ilişkilidir. Ekinci’nin (2011) yapmış olduğu çalışmada öğrencilerin akademik başarıları ile akademik öz-yeterlik düzeyleri arasında pozitif yönde anlamlı bir ilişkinin varlığı saptanmıştır. Lise öğrencilerinin kendi akademik potansiyellerine yönelik algılarının tespit edilmesinin, onların akademik yaşantılarının düzenlenmesine yönelik yapılacak çalışmalara katkı yapabileceği düşüncesi araştırmacılar tarafından önemli bulunan husus olmuştur. Bu araştırma lise öğrencilerinin akademik öz-yeterlik düzeylerinin tespit edilmesi ve onların akademik öz-yeterlik düzeylerinin bazı değişkenlere göre incelenmesi amaçlanmaktadır. Bu amaç doğrultusunda aşağıda yer alan sorulara cevap aranmıştır;

1. Lise öğrencilerinin akademik öz-yeterlik inançlarına ne düzeyde sahiptir?

2. Lise öğrencilerinin akademik öz-yeterlik inançları cinsiyet, okul türü, sınıf ve yatıl1/gündüzlü eğitim alma değişkenlerine göre anlamlı düzeyde farklılaşmakta mıdır?

\section{Yöntem}

$\mathrm{Bu}$ araştırmada öğrencilerin akademik öz-yeterlik inançlarını tespit etmeyi amaçlayan betimsel ve değişkenler arasındaki ilişkileri inceleyen korelasyonel bir çalışmadır. Betimsel araştırmalarda, var olan bir durumun mümkün olduğu kadar gerçeğe yakın bir şekilde tasvir edilmesi amaçlanırken, korelasyonel araştırmalarda ise değişkenler arasındaki ilişkiler incelenmektedir (Büyüköztürk, Çakmak, Akgün, Karadeniz ve Demirel, 2016).

\section{Araştırma evreni ve örneklemi}

Araştırmanın evrenini, 2018-2019 eğitim öğretim yılında Erzurum ili merkez Yakutiye İlçesi’nde öğrenim gören Anadolu, Fen ve Meslek lisesi öğrencileri teşkil etmektedir. Araştırmada 
kolayda örnekleme yöntemi ile belirlenen toplamda 624 Anadolu, Fen ve Meslek lisesi öğrencisine ulaşılmıştır. Kolayda örnekleme yönteminde araştırmacının çalışma evrenindeki kişileri kendi inisiyatifiyle daha kolay ulaşılması sonucunda veri kaynağ 1 olarak değerlendirdiği örnekleme yöntemlerindendir (Küçük, 2016). Tablo 1'de örneklemde bulunan öğrencilerin demografik özellikleri sunulmuştur.

Tablo 1: Lise öğrencilerinin kişisel özelliklerine göre dağılımı

\begin{tabular}{llll}
\hline Kişisel Özellikler & & f & \% \\
\hline \multirow{2}{*}{ Cinsiyet } & Kız & 344 & 55.1 \\
& Erkek & 280 & 44.9 \\
\hline \multirow{2}{*}{ Okul Türü } & Anadolu Lisesi & 249 & 39.9 \\
& Fen Lisesi & 178 & 28.5 \\
& Meslek Lisesi & 197 & 31.6 \\
\hline \multirow{4}{*}{ Sınıf } & 9. sinıf & 143 & 22.9 \\
& 10. sinıf & 165 & 26.4 \\
& 11. sınıf & 183 & 29.3 \\
\multirow{2}{*}{ Öğrenci Tipi } & 12. sinıf & 133 & 21.3 \\
\hline TOPLAM & Gündüzlü & 425 & 68.1 \\
\hline
\end{tabular}

Tablo 1'de incelendiğinde örneklemi olıuşturan 624 öğrencinin, 344'ü (\%55.1) k1z, 280'i (\%44.9) erkektir. Öğrencilerin 249'unun (\%39.9) Anadolu Lisesi’nde, 178'inin (\%28.5) Fen Lisesi'nde ve 197'sinin (\%31.6) Meslek Lisesi'nde öğrenim görmektedir. Öğrencilerin 143'ü (\%22.9) 9. sinıfta, 165'i (\%26.4) 10. sinıfta, 183'ü (\%29.3) 11. sinıfta ve 133'ü (\%21.3) 12. sinıftadır. Öğrencilerin 425'i (\%68.1) gündüzlü ve 199’u da (\%31.9) yatılı olarak öğrenim görmektedir.

\section{Veri toplama aracı}

Akademik Özyeterlik Ölçeği (AÖÖ): Akademik Özyeterlik Ölçeği (AÖÖ), Jerusalem ve Schwarzer (1981) tarafından geliştirilmiş, 7 maddeden oluşan ve 4'lü derecelendirmeye sahip bir ölçme aracıdır. Ölçekten alınabilecek puanlar 7-28 arasında değişmektedir. Ölçekteki son madde tersten puanlanmaktadır. Ölçeğin Türkçe'ye uyarlama çalışmaları ise Yılmaz, Gürçay ve Ekici (2007) tarafından yapılmıştır. Uyarlama çalışmasında geçerliğini incelemek amacıyla Açımlayıcı Faktör Analizi (AFA) yapılmış ve ölçeğin aynen orijinal ölçekte olduğu gibi 7 maddeden ve tek faktörden oluştuğu görülmüştür. Geçerlik çalışmasında ölçeğin faktör yüklerinin .50 ile .83 arasında değiştiği saptanmıştır. Ölçeğin güvenirliği ise Cronbach Alfa katsayısı ile hesaplanmış ve bu değerin .79 olduğu saptanmıştır. Bu sonuçlar ölçeğin geçerli ve güvenilir bir ölçme aracı olduğunu göstermektedir. $\mathrm{Bu}$ araştırma kapsamında da Cronbach Alfa katsayıs1 .72 olarak hesaplanmıştır.

\section{Verilerin analizi}

Araştırma verilerinin istatistiksel çözümleri için t-testi ve tek yönlü varyans analizi uygulanmış; frekans, yüzde ve ortalamalar hesaplanmıştır. Yapılan istatistiki çözümlemelerde anlamlılık düzeyi $\mathrm{p}<0.05$ olarak kabul edilmiştir.

Aritmetik ortalamaların yorumlanmasında; 1.00-4.00 arasındaki ortalama değerler hesaplanarak Tablo 2'de sunulmuştur. 


\begin{tabular}{lll} 
& \multicolumn{2}{c}{ Tablo 2: Ortalama puan katılma düzeyi } \\
\hline Verilen Ă̆ırlık & Yerine Getirme Dereceleri & Puan Aralığı \\
\hline 1 & Bana hiç uymuyor & $1.00-1.75$ \\
2 & Bana çok az uyuyor & $1.76-2.50$ \\
3 & Bana uyuyor & $2.51-3.25$ \\
4 & Bana tamamen uyuyor & $3.26-4.00$ \\
\hline
\end{tabular}

\section{Bulgular}

$\mathrm{Bu}$ bölümde lise öğrencilerinin akademik öz-yeterlik inançlarının düzeyine; cinsiyet, okul türü, sınıf ve öğrenci tipi değişkenler arasındaki farklılıklara yönelik bulgulara ve analiz sonuçlarına yer verilmiştir.

\section{Alt Problem 1. Lise ögrencileri akademik öz-yeterlik inançlarına ne düzeyde sahiptir?}

Lise öğrencilerinin genel olarak akademik öz-yeterlik inançlarına $\bar{x}=2.63$ ortalamayla "bana uyuyor" düzeyinde sahip oldukları saptanmıştır. Katılımcı görüşlerine göre aritmetik ortalama ve standart sapma değerleri Tablo 3 'te sunulmuştur.

Tablo 3: Lise öğrencilerinin akademik özyeterliğe sahip olma düzeyleri

\begin{tabular}{cllll}
\hline $\begin{array}{c}\text { Sura } \\
\text { No }\end{array}$ & Akademik Öz-yeterlik İnançlarına İlişkin Görüşler & $\mathbf{n}$ & $\overline{\mathbf{x}}$ & \multicolumn{1}{l}{ SS } \\
\hline 1 & Lise öğrenimimde her zaman yapılması gereken işleri başarabilecek durumdayım. & 624 & 2.88 & .952 \\
\hline 2 & Yeterince hazırlandığım zaman sınavlarda daima yüksek başarı elde ederim. & 624 & 3.04 & .981 \\
\hline 3 & İyi not almak için ne yapmam gerektiğini çok iyi biliyorum. & 624 & 2.85 & 1.01 \\
\hline 4 & Bir yazılı sınav çok zor olsa bile, onu başaracağımı biliyorum. & 624 & 2.60 & 1.03 \\
\hline 5 & Başarısız olacağım herhangi bir sınav düşünemiyorum. & 624 & 2.16 & .994 \\
\hline 6 & Sinav ortamlarında rahat bir tavır sergilerim, çünkü zekama güveniyorum. & 624 & 2.62 & 1.03 \\
\hline 7 & $\begin{array}{l}\text { Sinavlara hazırlanırken öğrenmem gereken konularla nasıl başa çıkmam gerektiğini } \\
\text { genellikle bilemem. }\end{array}$ & 624 & 2.22 & 1.11 \\
\hline
\end{tabular}

Tablo 3 incelendiğinde lise öğrencilerinin en yüksek ortalamayla "bana uyuyor" düzeyinde ifade ettikleri görüş "Yeterince hazırlandı̆̆ım zaman sinavlarda daima yüksek başarı elde ederim" $(\bar{x}=3.04)$ maddesidir. Lise öğrencilerinin en düşük ortalama ile "bana çok az uyuyor" düzeyinde ifade ettikleri görüş ise "Başarısız olacağım herhangi bir sınav düşünemiyorum" ( $\overline{\mathrm{x}}=2.16)$ maddesidir.

Alt Problem 2. Lise ögrencilerinin akademik öz-yeterlik inançlarına sahip olma düzeyleri ile cinsiyet, okul türü, sinıf ve öğrenci tipi değiş̧kenleri arasında anlamlı fark var mıdır?

Lise öğrencilerinin akademik öz-yeterlik ortalamalarının cinsiyet değişkenine göre $t$ testi sonuçları Tablo 4'te sunulmuştur.

Tablo 4: Öğrenci görüşlerinin cinsiyet değişkenine göre farklılığı

\begin{tabular}{lllllll}
\hline Cinsiyet & $\mathbf{n}$ & $\overline{\mathbf{x}}$ & SS & Sd & t & p \\
\hline K1z & 344 & 2.58 & 0.61 & \multirow{2}{*}{622} & -1.822 & .069 \\
Erkek & 280 & 2.68 & 0.63 & & & \\
\hline
\end{tabular}

Tablo 4'te akademik öz-yeterlik inançlarına yönelik öğrencilerin cinsiyet değişkenine göre puanları incelendiğinde; kı öğrencilerin $\overline{\mathrm{x}}=2.58$ ortalama; erkek öğrencilerin ise $\overline{\mathrm{x}}=2.68$ ortalama ile "iyi" düzeyinde görüşlerini ifade ettikleri görülmektedir. Kız ve erkek öğrencilerin cinsiyetlerine göre anlamlı farkl11ık olduğuna dair kanıta rastlanmamıştır $(\mathrm{t}=-1.822 ; \mathrm{p}=.069)$.

Öğrenci görüşlerinin okul türü değişkenine göre farklılığı Tablo 5 'te sunulmuştur. 
Tablo 5: Öğrenci görüşlerinin okul türü değişkenine göre farklılı̆̆

\begin{tabular}{|c|c|c|c|c|c|c|}
\hline $\begin{array}{l}\text { Varyansın } \\
\text { kaynağı }\end{array}$ & $\begin{array}{l}\text { Kareler } \\
\text { Toplamı }\end{array}$ & sd & $\begin{array}{l}\text { Kareler } \\
\text { Ortalaması }\end{array}$ & $\mathbf{F}$ & $\mathbf{p}$ & Fark \\
\hline Gruplar arası & 8.670 & 2 & 4.335 & & & $1>2,3$ \\
\hline $\begin{array}{l}\text { Gruplar içi } \\
\text { Toplam }\end{array}$ & 236.044 & 621 & .380 & $11.404^{*}$ & .000 & $2>3$ \\
\hline
\end{tabular}

Tablo 5'te akademik öz-yeterlik inançlarına yönelik öğrencilerin puanları incelendiğinde, okul türü değişkenine göre istatistiksel olarak anlamlı bir farkın olduğu saptanmıştır ( $\mathrm{F}=11.404$; $\mathrm{p}=.000)$. Farkların hangi gruplar arasında olduğunu saptamak amaciyla yapılan Scheffe testinin sonuçlarına göre Fen Lisesi öğrencilerinin $(\overline{\mathrm{x}}=2.78)$, Anadolu Lisesi öğrencilerine $(\overline{\mathrm{x}}=2.63)$ ve Meslek Lisesi öğrencilerine ( $\overline{\mathrm{x}}=2.48)$ göre; Anadolu Lisesi öğrencilerinin ( $\mathrm{x}=2.63)$, ise Meslek Lisesi öğrencilerine $(\overline{\mathrm{x}}=2.48)$ göre akademik öz-yeterlik inançları hakkındaki görüşleri daha olumludur.

Öğrenci görüşlerinin sınıf değişkenine göre farklılı̆̆ Tablo 6'da sunulmuştur.

Tablo 6: Öğrenci görüşlerinin sınıf değişkenine göre farkl11ı̆̆1

\begin{tabular}{lrrllll}
\hline $\begin{array}{l}\text { Varyansın } \\
\text { kaynağı }\end{array}$ & $\begin{array}{l}\text { Kareler } \\
\text { Toplamı }\end{array}$ & sd & $\begin{array}{l}\text { Kareler } \\
\text { Ortalaması }\end{array}$ & F & p & Fark $^{* *}$ \\
\hline Gruplar arası & 4.882 & 3 & 1.627 & $4.207^{*}$ & .006 & 9. Sınıf $>$ 10. Sinıf \\
Gruplar içi & 239.832 & 620 & .387 & & & \\
Toplam & 244.714 & 623 & & & & \\
\hline
\end{tabular}

$(*) \mathrm{p}<0.05$

Tablo 6'da akademik öz-yeterlik inançlarına yönelik öğrencilerin görüşleri incelendiğinde, sınıf değişkenine göre istatistiksel olarak anlamlı bir farkın olduğu tespit edilmiştir ( $\mathrm{F}=4.207$; $\mathrm{p}=.006$ ). Farkların hangi gruplar arasında olduğunu saptamak amaciyla yapılan Scheffe testinin sonuçlarına göre 9. sınıf öğrencilerinin $(\overline{\mathrm{x}}=2.73)$, 10. sınıf öğrencilerine $(\overline{\mathrm{x}}=2.53)$ göre akademik öz-yeterlik inançları hakkındaki görüşleri daha olumludur.

Öğrenci görüşlerinin gündüzlü/yatılı şekilde öğrenim görmelerine göre farkl1lı̆̆ Tablo 7'de sunulmuştur.

Tablo 7: Öğrenci görüşlerinin gündüzlü/yatılı şekilde öğrenim görmelerine göre farkl1lığı

\begin{tabular}{lllllll}
\hline Öğrenci Tipi & $\mathbf{n}$ & $\overline{\mathbf{x}}$ & SS & Sd & $\mathbf{t}$ & $\mathbf{p}$ \\
\hline Gündüzlü & 425 & 2.61 & 0.64 & 622 & -.633 & \multirow{2}{*}{.527} \\
Yatı11 & 199 & 2.65 & 0.58 & & \\
\hline
\end{tabular}

Tablo 7'de akademik öz-yeterlik inançlarına yönelik öğrencilerin gündüzlü/yatılı şekilde öğrenim görmelerine göre akademik öz-yeterlik puanları incelendiğinde; gündüzlü öğrencilerin $\overline{\mathrm{x}}=2.61$ ortalama; yatılı öğrencilerin ise $\overline{\mathrm{x}}=2.65$ ortalama ile "iyi" düzeyinde görüşlerini ifade ettikleri görülmektedir. Gündüzlü ve yatılı öğrencilerin gündüzlü/yatılı şekilde öğrenim görmelerine göre anlamlı düzeyde farklı1ık olmadığı saptanmıştır ( $\mathrm{t}=-.633$; $\mathrm{p}=.527)$.

\section{Sonuç, Tartışma ve Öneriler}

Erzurum ili merkez Yakutiye İlçesi'nde Anadolu, Fen ve Meslek liselerinde öğrenim gören 624 öğrencinden veriler toplanarak öğrencilerin akademik öz-yeterlik inançlarını belirleme amacını taşıyan bu araştırmada aşağıdaki sonuçlara ulaşılmıştır.

Araştırma sonuçlarına göre lise öğrencilerinin genel olarak akademik öz-yeterlik inançlarının "bana uyuyor" düzeyinde olduğu saptanmıştır. Bu sonuca göre, öğrencilerin özyeterlik inançlarına orta düzeyde sahip oldukları söylenebilir. Benzer şekilde Güldü’nün (2015) çalışmasında da lise öğrencilerinin akademik öz-yeterlik inançlarına "bana uyuyor" düzeyinde 
sahip oldukları saptanmıştır. Bozkurt ve Ekşioğlu'nun (2018) ve Gömleksiz ve Kılınç'ın (2014) çalışmalarında lise öğrencilerinin İngilizce öz-yeterlik inançlarının orta düzeyde olduğu tespit edilmiştir. Gökmen ve Ekici'nin (2012) çalışmalarında öğrencilerin biyoloji öz-yeterlik alg1 düzeylerinin yüksek olduğu, Güzel'in (2017) çalışmasında ise lise öğrencilerinin akademik özyeterlik inançlarının düşük düzeyde olduğu saptanmıştır. Lise öğrencilerinin en yüksek ortalamayla "bana uyuyor" düzeyinde ifade ettikleri görüş "Yeterince hazırlandı̆̆ım zaman sinavlarda daima yüksek başarı elde ederim" maddesidir. Lise öğrencilerinin en düşük ortalama ile "bana çok az uyuyor" düzeyinde ifade ettikleri görüş ise "Başarısız olacağım herhangi bir sinav düşünemiyorum" maddesidir.

Lise öğrencilerinin akademik öz-yeterlik inanç düzeyleri ile cinsiyetleri arasında istatistiksel olarak anlamlı farklılık olmadığı sonucuna ulaşılmıştır. Bu bulguya benzer şekilde Ay, Arslan, Adıgüzel ve Çoban'ın (2019), Ekinci'nin (2011) ve Güzel'in (2017) çalışmasında da cinsiyet değişkenine göre istatistiksel olarak anlamlı bir farklılık olmadığı saptanmıştır. Aynı zamanda Kurbanoğlu ve Takunyacı'nın (2012) çalı̧̧malarında da matematik dersine yönelik özyeterlik inançlarına sahip olma düzeyleriyle cinsiyetler arasında anlamlı bir farklılık saptanamamıştır. Ataş'ın (2018) ve Taşdemir'in (2012) çalışmasında erkekler lehine anlamlı bir farklılık tespit edilmiştir. Buna karşılık Bozkurt ve Ekşioğlu'nun (2018) çalışmalarında İngilizce Öz-yeterlik İnanç Ölçeğinin okuma ve dinleme boyutlarında kız öğrenciler lehine anlamlı bir farklılık olduğu saptanmıştır. Aynı zamanda Gökmen ve Ekici'nin (2012) çalışmalarında da Biyoloji Öz-yeterlik Ölçeğinin tüm boyutlarında ve ölçeğin genelinde kız öğrenciler lehine anlamlı bir farklılık olduğu saptanmıştır.

Lise öğrencilerinin akademik öz-yeterlik inançlarına sahip olma düzeyleri ile öğrenim gördükleri okul türü değişkeni arasında istatistiksel olarak anlamlı bir fark olduğu saptanmıştır. Fen Lisesi öğrencilerinin Anadolu Lisesi ve Meslek Lisesi öğrencilerinden; Anadolu Lisesi öğrencilerinin ise, Meslek Lisesi öğrencilerinden daha olumlu akademik öz-yeterlik inanç düzeylerine sahip oldukları tespit edilmiştir. Bu farkın sebebi, öğrencilerin başarı sıralamalarının esas alındığı sınav sonuçlarına göre girdikleri okul türlerinin akademik öz-yeterlik algılarını şekillendirmiş olması olabilir. Taşdemir'in (2012) çalışmasında lise öğrencilerinin akademik özyeterlik inançlarına sahip olma düzeyleri ile öğrenim gördükleri okul türleri olan Fen Lisesi, Genel Lise ve Anadolu Lisesi öğrencileri arasında Fen Lisesi öğrencileri lehine; Anadolu Öğretmen Lisesi, Genel Lise ve Anadolu Lisesi öğrencileri arasında ise Anadolu Öğretmen Lisesi lehine anlamlı bir farklılık olduğu saptanmıştır. Özgen ve Bindak'ın (2011) çalışmalarında Genel Lise, Anadolu Lisesi ve Meslek Lisesi öğrencileri arasında Anadolu Lisesi lehine; Genel Lise ile Meslek Lisesi öğrencileri arasında ise Genel Lise lehine anlamlı bir farklılık olduğu saptanmıştır. Aksu'nun (2015) çalı̧̧masında Anadolu lisesi, Çok Programlı Lise ve Mesleki Teknik Eğitim Lisesi öğrencileri arasında Anadolu Lisesi öğrencileri lehine anlamlı bir fark olduğu tespit edilmiştir. Kurbanoğlu ve Takunyacı'nın (2012) çalı̧̧malarında Anadolu Lisesi ile Düz Lise ve Meslek Lisesi öğrencileri arasında Anadolu Lisesi öğrencileri lehine anlamlı bir farklılık tespit edilmiştir. Ekinci'nin (2011) çalışmasında İmam Hatip Lisesi öğrencilerinin akademik öz-yeterlik düzeylerinin Genel Lise, Anadolu Lisesi, Anadolu Öğretmen Lisesi ve Ticaret Meslek Lisesi öğrencilerinin akademik öz-yeterlik düzeylerden anlamlı şekilde düşük çıktığı tespit edilmiştir. Bozkurt ve Ekşioğlu'nun (2018) çalışmalarında lise öğrencilerinin İngilizce öz-yeterlik inanç düzeylerinin, tüm alt boyutlarda Anadolu Lisesi öğrencileri lehine anlamlı farklılık gösterdiği, ayrıca yazma ve konuşma alt boyutlanında, İmam Hatip Lisesi öğrencileri ile Endüstri Meslek Lisesi öğrencileri arasında İmam Hatip Lisesi öğrencileri lehine anlamlı bir farklılık olduğu saptanmıştır. Sezer, İşgör, Özpolat ve Sezer'in (2006) çalışmalarında sınavla ve yetenekle öğrenci alan okullar ile genel liseler arasında sinavla ve yetenekle öğrenci alan okullar lehine anlamlı bir farklılık olduğu tespit edilmiştir. Güldü'nün (2015) çalışmasında ise okul türü değişkenine göre anlamlı bir farklılık saptanamamıştır. 
Lise öğrencilerinin akademik öz-yeterlik inançlarına sahip olma düzeylerine ilişkin görüşleri ile öğrenim gördükleri sınıf değişkenine göre öğrencilerin görüşleri arasında anlamlı bir fark bulunmuştur. 9. sinıf öğrencilerinin akademik öz-yeterlik inanç düzeylerinin, 10. sınıf öğrencilerinin akademik öz-yeterlik inanç düzeylerinden daha olumlu olduğu sonucuna ulaşılmıştır. Aksu'nun (2015) çalışmasında 10. sınıf öğrencilerinin diğer sınıflarda öğrenim gören öğrencilerden akademik öz-yeterliklerinin anlamlı düzeyde düşük olduğu saptanmıştır. Buna karşılık Bozkurt ve Ekşioğlu'nun (2018) çalışmalarında lise öğrencilerinin İngilizce öz-yeterlik inanç düzeylerinin, tüm alt boyutlarda 10. sınıf öğrencilerinin lehine olduğu saptanmıştır. Ekinci'nin (2011) çalışmasında 12. sınıf öğrencileri ile 9. sınıf öğrencileri arasında 12. sınıf öğrencileri lehine anlamlı bir farklılık tespit edilirken Özgen ve Bindak'ın (2011) çalışmalarında ise 9. sınıf öğrencileri ile 12. sınıf öğrencileri arasında 9. sınıf öğrencileri lehine anlamlı bir farklılık saptanmıştır. Kurbanoğlu ve Takunyacı'nın (2012) çalışmalarında öğrencilerinin matematik dersine yönelik öz-yeterlik inançlarının, sınıf düzeyi arttıkça yükseldiği tespit edilmiştir. Ataş’’n (2018), Ay ve diğerlerinin (2019) çalışmasında ise sınıf düzeyi değişkenine göre anlamlı bir farklılık bulunamamıştır.

Son olarak lise öğrencilerinin akademik öz-yeterlik inançlarına sahip olma düzeylerin öğrencilerin yatıl1/gündüzlü öğrenim görmeleri açısından incelendiğinde anlamlı bir farklılaşma olmadığı saptanmıştır. Alan yazın incelendiğinde Beker-Baş, Çakır ve Karamustafaoğlu'nun (2019) da yaptıkları araştırmada yatılı ve gündüzlü okuyan öğrencilerinin akademik öz-yeterlik düzeylerinin anlamlı olarak farklılaşmadığı saptanmıştır. Bu sonuç araştırmanın bulgularıyla paralellik göstermektedir. Bu sonuç yatılı ya da gündüzlü olmanın akademik öz-yeterliğin belirleyicilerinden olmadığı şeklinde yorumlanabilir.

Her araştırmada olduğu gibi bu araştırmada da bir takım sınırlıklar bulunmaktadır. Çalışma verilerinin tek bir ilçeden toplanması, sadece nicel araçlarla verilerin toplanması bu araştırmanın önemli sinırlıklarındandır. $\mathrm{Bu}$ bağlamda sonraki araştırmalarda nicel verilerin nitel verilerle desteklenmesi ve daha farklı bölgelerde de uygulama yapılması daha sağlıklı değerlendirmeler ve genellemeler yapılabilmesi noktasında yol gösterebilir. Sonraki araştırmalarda öğrencilerin akademik öz-yeterlik inançlarına etki eden etmenler araştırılabilir. Bu araştırma resmi ortaöğretim kurumlarında öğrenim gören öğrencilerin akademik öz-yeterlik inanç düzeylerini belirleme amaçlı yapılmıştır. Özel ortaöğretim kurumlarında öğrenim gören öğrencilerin akademik öz-yeterlik inanç düzeyleri de araştırılabilir.

\section{Kaynakça}

Ağır, M. (2005). Sosyal öğrenme kuramı. B. Aydın (Ed.), Gelişim ve öğrenme (ss:229-257). Nobel Yayın Dağıtım.

Akınc1, T. (2014). Sosyal bilişsel teori. A. Bakioğlu (Ed.), Eğitim psikolojisi (ss:261-280). Nobel Akademik Yayıncilik.

Aksu, N. (2015). The research of the relationship between the academic self-competence, social relation elements and crime tendency of the high school stodents [Unpublished Master Thesis]. Zirve University Institute of Social Sciences.

Ataş, N. S. (2018). Ergenlerin akademik erteleme davranışları, akademik öz yeterlik inançları ve mükemmeliyetçilik düzeyleri [Yayımlanmamış Yüksek Lisans Tezi]. Ondokuz Mayıs Üniversitesi Eğitim Bilimleri Enstitüsü.

Ay, Ş. Ç., Arslan, F. Z., Adıgüzel, İ., \& Çoban, K. (2019). Lise öğrencilerinin akademik özyeterlik algısı ve akademik erteleme davranışı arasındaki ilişki. Düzce Üniversitesi Sosyal Bilimler Enstitüsü Dergisi, 9(1), 116-126. 
Aydın, B. (2006). Öğrenilmiş çaresizliğin yordanması ve yaşam başarısı ile ilişkisi [Yayımlanmamış Yüksek Lisans Tezi]. Mersin Üniversitesi Sosyal Bilimler Enstitüsü.

Bandura, A. (1977). Self-efficacy: toward a unifying theory of behavioral change. Psychological review, 84(2), 191-215.

Bandura, A. (1986). Social foundations of thought and action: A social cognitive theory. Englewood Cliffs. PrenticeHall.

Bandura, A. (1995). Exercise of personal and collective efficacy in changing societies. In A. Bandura (Ed.), Self-efficacy in changing societies (pp. 1-45). Cambridge Univ. Press.

Beker-Baş, M., Çakır, R., \& Karamustafaoğlu, O. (2019). Yatılı ve gündüzlü öğrencilerin bireysel ve sosyal sorumluluk ile akademik özyeterlik algıları arasındaki ilişki, 3. Uluslararası Bilim ve Ĕ̈itim Kongresi- UBEK-ICSE 2019, Bildiri kitab1 s: 492-498, 21-24.

Bozkurt, M. A., \& Ekşioğlu, S. (2018). Lise öğrencilerinin İngilizce öz-yeterlik düzeyleri. Kırşehir Ĕgitim Fakültesi Dergisi, 19(1), 440-452.

Büyüköztürk, Ş., Çakmak, E. K., Akgün, Ö. E., Karadeniz, Ş., \& Demirel, F. (2016). Bilimsel araştırma yöntemleri. (22. Bask1). Pegem Akademi.

Çakır, M. A. (2007). Sosyal bilişsel öğrenme kuramı. A. Kaya (Ed.), Eğitim psikolojisi (ss:411438). Pegem A Yayınc1lik.

Chemers, M. M., Hu, L. T., \& Garcia, B. F. (2001). Academic self-efficacy and first year college student performance and adjustment. Journal of Educational psychology, 93(1), 55-64.

Ekinci, E. (2011). Ortä̈ğretim ögrrencilerinin akademik öz-yeterlik düzeyleri ve akademik erteleme davranışlarının ögrenilmiş çaresizlik düzeylerini yordama gücü [Yayımlanmamış Yüksek Lisans Tezi]. Gaziosmanpaşa Üniversitesi Sosyal Bilimler Enstitüsü.

Gökmen, A., \& Ekici, G. (2012). Ortaöğretim öğrencilerinin biyoloji öz-yeterlik alg1 düzeyleriyle öğrenme stilleri ilişkisinin değerlendirilmesi. Gazi Eğitim Fakültesi Dergisi, 32(3), 843866.

Gömleksiz, M. N., \& Kılınç, H. H. (2014). Lise 12. sınıf öğrencilerinin İngilizce öz yeterlik inançlarına ilişkin görüşleri. Fırat Üniversitesi Sosyal Bilimler Dergisi, 24(2), 43-60.

Güldü, S. (2015). Analysis of the relation between school metaphors, academical self efficacy and high school life quality in line with the views of the students at high schools [Unpublished Master Thesis]. Zirve University Institute of Social Sciences.

Güzel, H. (2017). Lise öğrencilerinin akademik öz-yeterlik inanç düzeylerinin internet kullanımı ve bazı değişkenler açısından incelenmesi. Uluslararası Eğitim Bilimleri Dergisi, 11, 225245 .

Jerusalem, M., \& Schwarzer, R. (1981). Fragebogen zur erfassung von "selbstwirksamkeit. skalen zur befindlichkeit und persoenlichkeit In R. Schwarzer (Hrsg.). (Forschungsbericht No. 5). Freie Universitaet, Institut fuer Psychologie.

Kalkan, M. (2008). Sosyal öğrenme kuramı. Y. Özbay ve S. Erkan (Ed.), Eğitim psikolojisi (ss:289313). Pegem Akademi.

Kandemir, M. (2015). Öz yeterlik. B. Ergüner Tekinalp ve Ş. Iş1k Terzi (Ed.), Eğitimde pozitif psikoloji uygulamalar (ss:39-74). Pegem Akademi.

Korkmaz, İ. (2011). Sosyal öğrenme kuramı. B. Yeşilyaprak (Ed.), Eğitim psikolojisi: Eğitimögrenme-öğretim (ss:245-269, 8. Baskı). Pegem Akademi. 
Kotaman, H. (2008). Özyeterlik inancı ve öğrenme performansının geliştirilmesine ilişkin yazın taraması. Uludă̆ Üniversitesi Eğitim Fakültesi Dergisi, 21(1), 111-133.

Küçük, O. (2016). Bilimsel araştırma yöntemleri. Ekin Basın Yayın Dağıtım.

Kurbanoğlu, N. İ., \& Takunyacı, M. (2012). Lise öğrencilerinin matematik dersine yönelik kayg1, tutum ve öz-yeterlik inançlarının cinsiyet, okul türü ve sınıf düzeyi açısından incelenmesi. Uluslararası İnsan Bilimleri Dergisi, 9(1), 110-130.

Özgen, K., \& Bindak, R. (2011). Lise öğrencilerinin matematik okuryazarlığına yönelik öz-yeterlik inançlarının belirlenmesi. Kuram ve Uygulamada Eğitim Bilimleri, 11(2), 1073-1089.

Pajares, F. (1996). Self-efficacy beliefs in academic settings. Review of Educational Research, 66(4), 543-578.

Pajares, F. (2008). Motivational role of self-efficacy beliefs in self-regulated learning. In D. H. Schunk \& B. J. Zimmerman (Eds.), Motivation and self-regulated learning: Theory, research, and applications (pp. 111-139). Lawrence Erlbaum Associates.

Santrock, J. W. (2018). Eğitim psikolojisi (D.M. Siyez, Çeviri Editörü). Nobel Akademik Yayınc1lik.

Schunk, D. H. (1984). Enhancing self-efficacy and achievement through rewards and goals: Motivational and informational effects. The Journal of Educational Research, 78(1), 2934.

Schunk, D. H. (1991). Self-efficacy and academic motivation. Educational Psychologist, 26, 207231.

Senemoğlu, N. (2015). Gelişim, öğrenme ve ögretim: Kuramdan uygulamaya (24. Bask1). Yarg1 Yayınevi.

Sezer, F., İşgör, İ. Y., Özpolat, A. R., \& Sezer, M. (2006). Lise öğrencilerinin öz yeterlik düzeylerinin bazı değişkenler açısından incelenmesi. Atatürk Üniversitesi Kazım Karabekir Ĕ̈itim Fakültesi Dergisi, (13), 129-137.

Taşdemir, C. (2012). Lise son sınıf öğrencilerinin matematik öz-yeterlik düzeylerinin bazı değişkenler açısından incelenmesi (Bitlis ili örneği). Karadeniz Fen Bilimleri Dergisi, 2(6), 39-50.

Ün-Açıkgöz, K. (2005). Etkili öğrenme ve öğretme (6. Baskı). Eğitim Dünyası Yayınları.

Yılmaz, M., Gürçay, D., \& Ekici, G. (2007). Akademik özyeterlik ölçeğinin Türkçe’ye uyarlanması. Hacettepe Üniversitesi Eğitim Fakültesi Dergisi, 33, 253-259.

Zimmerman, B. J. (1995). Self-efficacy and educational development. Self-efficacy in Changing Societies, 1, 202-231. 